\title{
The Next Frontier
}

\section{Collaboration in the New Economy}

Playing together isn't just more fun; it's better business.

Collaboration connects players-plain and simple. And that

leads to more creativity and more innovation.

-Research Triangle Regional Partnership (2013)

In all of the case-study regions we've examined up to this point, we have stressed the role and evolution of epistemic communities, often against the backdrop of significant economic restructuring, growing demographic diversity, and a nationwide worsening of inequality. We've explored the differences between communities that are driven by planning, steered by elites, or wracked by conflict. We have suggested that although processes of collaboration and knowledge-sharing across diverse constituencies do not guarantee success, they may help create norms and conditions that make above-average growth and improved social equity more likely to be achieved, even in the midst of a rapidly changing economy.

With perhaps the exception of Salt Lake City, the regions we have examined so far have not been at the leading edge of the economic restructuring of the past thirty years. So, what about regions that have been at the forefront of developing the new industries and technologies that are shaping our new "knowledge economy"? What role do epistemic communities play in regions whose very economic base is rooted in the commercialization of new scientific and technological knowledge? In these areas, knowledge matters in two ways. The first is simply the products: the high-technology industries and firms we associate with the new economy rely on the advance of science and technological know-how. But just as important is the second way in which knowledge matters: research on innovation and new-technology development has 
demonstrated time and again that collaboration and dense informationsharing networks are key factors in explaining economic innovation (Braczyk, Cooke, and Heidenreich I998; Brown and Duguid 2000; Saxenian 1994).

However, there is also research that argues that the sort of rapid technological change we see most dramatically in these new economy regions is associated with increasing inequality (Autor, Katz, and Kearney 2006; Brynjolfsson and McAfee 20II). For example, Silicon Valley, the iconic global high-tech region, has received significant public scrutiny as a place with extreme contrasts (Packer 2013) -and the spectacle of local residents protesting against buses shuttling Google employees from urban San Francisco to their suburban coding cubicles has certainly captured the public's imagination. Since we have stressed the role of knowledge and interaction in helping facilitate situations in which such disparities might receive attention, is there a contradiction in our approach? What happens when a knowledge community meets the knowledge economy?

In this chapter we examine three regions-Silicon Valley, RaleighDurham, and Seattle-which have large information technology industries and have built their regional economies around growth in these industries. As we'll see, the three have quite different patterns of both growth and social equity. In Silicon Valley, economic growth and social equity seemed to go together (to a certain extent) in the r980s, but this has eroded in recent years as the region has continued to experience dramatic increases in income alongside rapidly increasing inequality and stagnant job growth. In contrast, Raleigh-Durham and Seattle have experienced substantial economic growth and indicators of social equity that are above average-and Seattle adopted the nation's highest municipal minimum wage ordinance in 2014 , an effort to address some of the disparities that are supposedly being generated by the more dynamic parts of its regional economy.

This contrast suggests to us that there is nothing inherent in being dependent on information technology industries that condemns a region to worsening inequality, and that much depends as well on the regional norms and networks. In what follows, we first examine Silicon Valley, discussing the evolution of the region's governance from a contested but engaged business-led vision of regional stewardship, to increasing divisions and the growth of what has been called a "tale of two valleys" (Kuchler 20I4). This case is a bit shorter than others in the book because the Valley has been extensively profiled elsewhere, including by 


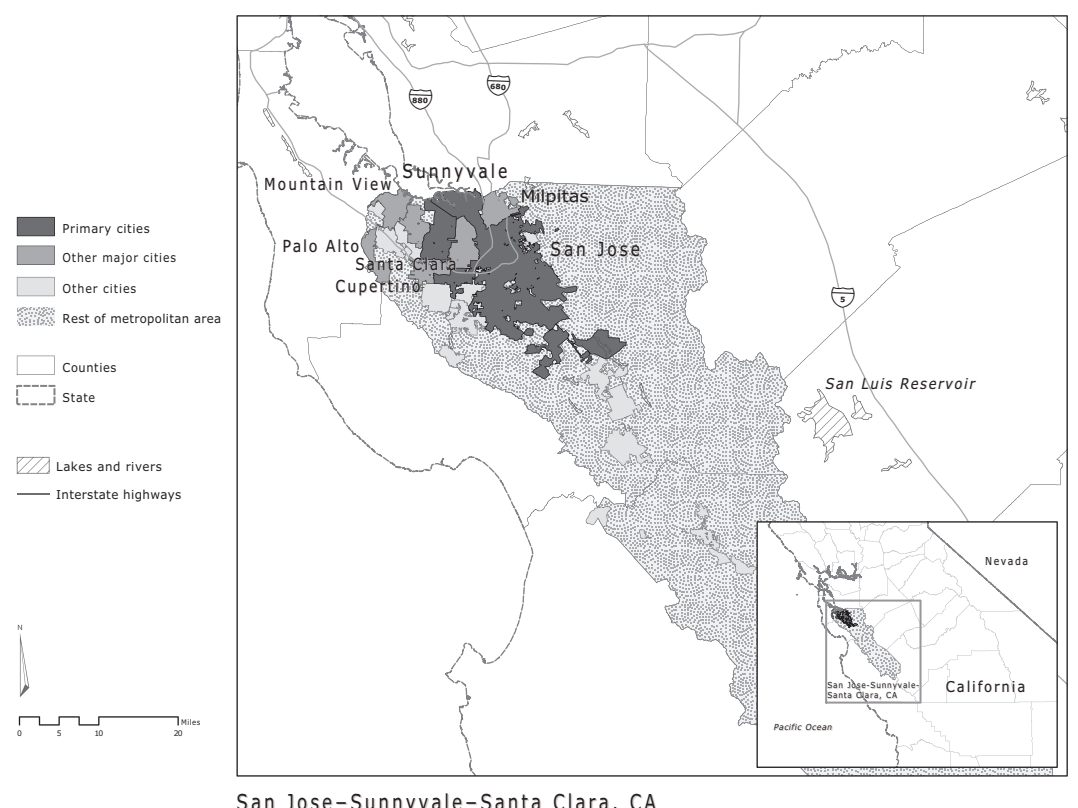

MAP 7.I. Silicon Valley Region.

us (Benner 2002; Pastor et al. 2000). We then turn to Raleigh-Durham, where the Triple Helix model of regional governance, combined with a strong and networked social equity advocacy and research organization, have helped maintain the region's dynamism and relatively equitable growth. Finally, in Seattle, we explore how a culture of consensus-building and broad participation-sometimes to a fault-has contributed to a quite remarkable set of processes that certainly suggest the presence of a dynamic and diverse epistemic community.

\section{SILICON VALLEY}

Silicon Valley is well known as the global center of innovation in hightechnology industries. ${ }^{\mathrm{T}}$ The region has managed to maintain its innovative leadership through multiple rounds of economic restructuring; it has been consistently able to develop new technological innovations even as yesterday's innovative technologies become more commoditized and globalized, and so migrate to other high-tech regions and lowercost production centers. From the heart of the semiconductor and related integrated-circuit industry in the I960s and I970s, through the 
explosion of personal computers in the I980s, through the software and Internet boom of the I990s, and now into social media, the region has remained at the cutting edge of new technological innovations and related economic growth.

What has shifted over the years is the extent to which this economic growth has been associated with broad social inclusion. In the r980s, growth and improved equity seemed to go hand in hand, and the Valley was actually home to a sizable middle-class population. More recent statistics show an erosion of these links, even as the sort of regional cohesion that led to the formation of many important collaborations, such as the Silicon Valley Manufacturing Group (I977) and Joint Venture Silicon Valley (I993), seems to have cracked in the most recent decade.

This shift is all the more remarkable because it was the strong collaboration in the Valley, epitomized by the public-private partnership Joint Venture Silicon Valley, which was held up as the premier example for a national movement of business-led regional stewardship that evolved in the late I990s and early 2000s, and that we discussed in chapter 5 (Henton and Alliance for Regional Stewardship 2000; Henton 2003). The influence of Joint Venture has waned since the early I990s, however, with some suggesting that the general erosion of a sense of civic responsibility is due to the spatial spreading of high-tech beyond the core of Silicon Valley (both regionally and globally). Meanwhile, to the extent that wealthy communities in Silicon Valley have concern for those who are less fortunate, it seems to be rooted in a culture of libertarian technological possibilities, rather than a sense of collective responsibility. The result has been a deepening of inequality in the region, a sense of marginalization in poorer communities, and a growing divide into "two valleys."

\section{Drifting Apart, Drifting Away}

The I980s were good times for growth and equity in Silicon Valley. During that decade, employment in the San Jose metro region (the core of Silicon Valley) grew by 29 percent, slightly less than the average job growth rate for metropolitan areas in the West but above the national average of 26 percent. In the same period, average earnings grew substantially, up I 8 percent, compared to I percent across western metros and 3 percent across the country. The region's performance on equity indicators during the I980s was also among the best. While the West 
and the nation experienced I 2- and 6-percent growth in poverty, respectively, during this time, Silicon Valley's poverty grew by only 4 percent. Meanwhile, household income at the 20 th percentile grew dramatically in the I980s, rising from $\$ 32$, II 4 in I979 to $\$ 4$ I, I 46 in I989 (in 20 IO dollars). As a result, the $80 / 20$ income ratio declined by 6 percent, better than the 5-percent decline across all metro regions in the West and substantially better than the I-percent decline in the average US metro.

This happy combination of growth and equity began to break down in the I990s (Benner 1996, 2002), and the decoupling accelerated following the dot-com bust in 2000 . The decade of the 2000 s saw a dramatic increase in inequality, as job growth stagnated and earnings at the bottom of the income structure plummeted. Even while the overall regional economy grew in the 2000s, according to statistics from the US Bureau of Economic Analysis, net employment over the decade actually declined by $\mathrm{I} 2$ percent. Average earnings also fell by I 2 percent, poverty increased by nearly 40 percent, and inequality (as measured by the $80 / 20$ household income ratio) grew by nearly 26 percent-all substantially worse than the average for other metros in the West and the average across the whole country. Furthermore, in the twenty-one-year period between I990 and $20 \mathrm{II}$, the longest growth spell the region was able to produce was seven years, from I994 to $200 \mathrm{I}$, putting it in the bottom half of metros in the growth-spell analysis in chapter 2 . And all these dismal statistics were posted despite its being the global center of high-technology industries, the most dynamic and rapidly growing sector of the world economy during that time period.

Why didn't the economic growth of the Internet boom in the late I990s translate into more broadly shared opportunity? Why wasn't the region better able to respond in a positive way to the economic challenges following the dot-com collapse? After all, Silicon Valley was the home to Joint Venture Silicon Valley, founded in I 993 specifically to "provide analysis and action on issues affecting [the] region's economy and quality of life."

Here is one important factor in explaining the poor performance. The region's reputation for strong collaborative knowledge networks is rooted primarily in high-tech industries, rather than the region per se (Saxenian 1994; Storper 1997). In addition, the sense of place identity that seemed to dominate the high-tech industry in the I980s and I 990 s seems to have eroded, partly because of two processes that have weakened the rootedness of high tech in Silicon Valley. The first was a process of diffusion beyond the historical borders of Silicon Valley, 
a process which began in the I980s and accelerated after the dot-com crash of 2000. Most obvious has been the rapid expansion of social media and other Internet media firms in San Francisco, but this was accompanied by the expansion of telecommunications firms in the north Bay Area, various manufacturing facilities on the eastern side of the Bay, and even major facilities (for Intel, Apple, and Hewlett Packard) farther east, in the Sacramento region. This led to a dilution of the high-tech industry's attention to the regional development challenges of Silicon Valley itself, such as traffic congestion, skyrocketing housing prices, and growing economic divides.

Perhaps as significantly, with the increasing diffusion of broadband Internet and associated increasing sophistication in global communication systems, new startups and other growing companies pioneered a new model of company development. Rather than historical patterns of growing initially in a company headquarters and subsequently expanding to more distant locations, companies discovered that they could be established and grow as "micro-multinationals" from the very beginning, with in fact the largest portion of their highly skilled workforce in lower-cost locations like India, China, and to a lesser extent Taiwan, and a much smaller staff in Silicon Valley itself (Copeland 2006; Varian 2OII). These broad trends in the region's dominant high-tech sector worked against regional integration and cross-sector knowledge sharing.

\section{Institutionalizing Voice}

Business leadership in the region over the past three decades has been somewhat fragmented as well, further weakening the region's ability to respond to these challenges. The Silicon Valley Leadership Group (SVLG), formerly known as the Silicon Valley Manufacturing Group (which suggests something that many observers forget-there was once manufacturing in the Valley that helped develop and sustain a middle class), represents the largest employers in the region, with a strong emphasis on high-tech industries. ${ }^{3}$ The organization was founded in I977, when David Packard (of Hewlett-Packard fame) brought together a number of fellow CEOs with the premise that local employers should be actively working with government to find solutions to regional issues, like transportation, housing, permit streamlining, education, and the environment. ${ }^{4}$ As of 2013 , the organization had over 375 member companies, which purportedly account for one out of three privatesector jobs in the region. 
The organization has been an important voice for broader regional development initiatives and was a major force in promoting affordable housing, something that helped its members' employees but also poorer residents throughout the region (Pastor et al. 2000, I36). In recent years, however, the group seems to be more narrowly aimed at the needs of the member companies. For example, its transportation work has focused on advocating for the extension of the regional mass transit system, BART, to San Jose, rather than on expansion of the more localized bus system on which poorer people in the region depend. Meanwhile, more than forty major Silicon Valley companies, including Google, Facebook, and Apple, are operating their own exclusive bus systems, and frequently using public bus stops to pick up their employees (Henderson 20I3). While they benefit employees and probably reduce greenhouse-gas emissions, the private bus services have been heavily criticized for crowding out other forms of mass transit and undermining potential economic and political support for expanding a truly public transit service (Eberlein 20I3; Millner 20I3).

The housing policy of the SVLG seems to have narrowed in its orientation as well. The work is avowedly motivated by the barrier high housing costs create to "recruiting and retaining top talent to Silicon Valley" ${ }^{2}$ rather than a concern for the extremely high housing-cost burden facing existing low- and moderate-income residents of the Valley. Meanwhile, those same high housing costs have contributed to levels of homelessness that are truly shocking in such a wealthy region, including a long-standing 68-acre homeless camp, dubbed the Jungle, which was widely regarded as the largest homeless camp in the country until it was cleared out in early December 20I4 (Campbell and Flores 20I4; Grady 20I4; Nieves 2000).

While the Silicon Valley Leadership Group has become the most prominent voice for large business in the region, the San Jose Silicon Valley Chamber of Commerce remains the largest and oldest business chamber in the region. Founded in I886, the chamber has over I, 500 members and includes many more of the region's small, medium, and family-owned businesses. Like many other chambers, it has been largely reactive and traditional in its policy stances, partly reflecting the small and local businesses that are the largest source of its membership. For example, it strongly opposed both San Jose's I998 Living Wage Ordinance and a $20 \mathrm{I} 2$ city-wide minimum-wage proposal, while the SVLG took a neutral stance on both campaigns. A controversial public-sector pension reform initiative on the $20 \mathrm{I} 2$ ballot, seen by public-sector unions as a 
direct attack on their very existence, was also pushed by the chamber while the SVLG remained on the sidelines. ${ }^{6}$

As noted above, the most prominent effort at regional collaboration in Silicon Valley in the last twenty years was Joint Venture Silicon Valley. Predominantly business-led, Joint Venture also had substantial involvement from the public sector and educational institutions and showed some significant promise in addressing a wide range of concerns in the region, including social infrastructure and quality of life (JVSVN I995). But its primary social intervention (the $2 \mathrm{I}^{\text {st }}$ Century Education Initiative) involved an attempt at reforming the K-I 2 education system, through "Renaissance teams" of varied education stakeholders. Renaissance gave way to stasis: a detailed review of the initiative noted that there was no systematic effort to track student outcomes, and found "little evidence that [the initiative] produced systemic change across Silicon Valley" (Saxenian and Dabby 2004, I3).

On broader issues of social inequality in the region, and on sustained patterns of racial discrimination, Joint Venture has been largely silent. The organization did begin to incorporate indicators of poverty and social inequality into its signature annual indicator report (Benner I996; JVSVN I999; Pastor, Benner, and Matsuoka 2009). But Joint Venture has failed to undertake any significant initiative that would impact large sectors of disadvantaged communities in the region. Partly as a result, labor and community allies have developed their own institutional voice, Working Partnerships USA, which has helped lead fights for a living wage, more affordable housing, and the extension of health insurance, including to undocumented children, in Santa Clara County (Benner and Dean 2000; Dean and Reynolds 2009).

This sort of a political balance-in which the business voice is countered and then coupled with labor and community concerns-could be a recipe for finding a happy medium. But rather than knowledge being pooled, the Valley has been host to competing policy reports, annual indicator measures, and data displays. The forging of a common regional identity grounded in shared processes of knowledge generation and interpretation has been elusive, particularly because one of the natural sources of civic leadership — the business community-has been globalized in its perspective and individualistic in its approach. Business leaders are far more likely to think that education alone will solve every social ill-partly because education paid off for them personally-while community leaders see the obstacles that migration status, low wages, and inadequate school spending pose to their futures. 


\section{A Tale of Two Valleys}

Ultimately what has emerged is a region that our key informants almost universally described as fragmented and divided, with the high-tech community largely isolated from the broader region and particularly those parts of the region that are less fortunate. The "tale of two valleys," which had been a minor (though important) theme in media coverage and academic accounts of the Valley's development in the I970s and I 980 s, started becoming more prevalent in the I990s and by 2013 had reached major national prominence. The Valley was highlighted in a Bill Moyers special called "The United States of Inequality," 7 as well as in a devastating portrayal in the New Yorker of the high-tech industry's myopia with regard to social problems (Packer 2013).

With few opportunities for meaningful regular interaction between growth and equity constituencies-even between high-tech executives and the Latino immigrant security guards protecting their facilitiesit is perhaps no surprise that the "disruptive innovations" developed out of the dominant high-tech industries in the region are not always what is most needed. As George Packer (2013) put it, entrepreneurs are "solving all the problems of being twenty years old, with cash on hand, because that is who thinks them up," rather than addressing problems challenging society at large, such as growing inequality and poverty.

That such contact can make a difference is evidenced by the transformation of Facebook cofounder Mark Zuckerberg into a campaigner for immigration reform—and not just for visas for high-tech workers. As he describes it:

Earlier this year I started teaching a class on entrepreneurship at an afterschool program in my community. . . . One day I asked my students what they thought about going to college. One of my top aspiring entrepreneurs told me he wasn't sure that he'd be able to go to college because he's undocumented. His family is from Mexico, and they moved here when he was a baby. Many students in my community are in the same situation; they moved to the United States so early in their lives that they have no memories of living anywhere else. (Zuckerberg 20I3)

It is that sort of interaction with the "other" that can lead to trust, collaboration, and concern about equity and fairness. This is of course difficult in the highly atomized world of Silicon Valley, and appearancesin this case, of an easy acceptance of talented engineers from around the world—can be deceiving. Indeed, a key survey of social capital conducted in 2000 in communities across the United States found that people in Silicon Valley were more likely than in comparable regions to 
have friendships that crossed racial lines, but less likely than elsewhere to have friendships that crossed lines of income and class. ${ }^{8}$

It's an epistemic community all right, but the diversity is frequently lacking and, once again, despite appearances, so too is regional dynamism. The Valley may host Google, Apple, and Facebook (along with countless smaller companies), but the regional economy continues to be highly volatile, with the cycles of boom and bust resulting in zero net job growth between I997 and 2013. If we want to ensure that the knowledge economy delivers in a broader and more sustained fashion, we may need to look elsewhere-and so we turn below to Raleigh and Seattle, which have taken different approaches to creating more cohesive processes of knowledge generation and interpretation.

\section{RALEIGH-DURHAM}

Raleigh-Durham provides an important comparison with Silicon Valley because it is a place where technology-driven growth and social equity have gone together in a more sustained way (though with some slippage in recent years) and where knowledge networks in and about the region seem to be more diverse and more intentional. ${ }^{9}$ At the same time, Raleigh-Durham is home to a vibrant high-tech industry, a trio of world-class universities, and a renowned public school system, luring businesses and residents from across the country to relocate there. Indeed, over the last thirty years, Raleigh-Durham has easily outperformed its counterparts in the American South.

Between I980 and 2010, for example, it nearly tripled the number of jobs and increased average earnings by almost 50 percent. While most regions have only experienced growth in low-wage sectors, or extreme polarization with almost zero growth in middle-class jobs, job growth in Raleigh since I990 has occurred primarily in mid-wage industries (an 84-percent increase) and low-wage industries (a 73-percent increase), while jobs in high-wage industries increased by about one-quarter. On the other hand, while high-wage industries grew at a lower rate, these workers experienced a larger increase in earnings (56 percent) than workers in mid-wage ( 28 percent) and low-wage industries ( 23 percent). Nonetheless, the Raleigh-Durham region bolstered its middle class at a higher rate than other regions, with jobs in middle-wage industries rising from 3 I percent of jobs in I 990 to 36 percent of jobs in 2010 .

Indeed, while income inequality in Raleigh-Durham has increased, this happened at a much lower rate than in comparable metros between 


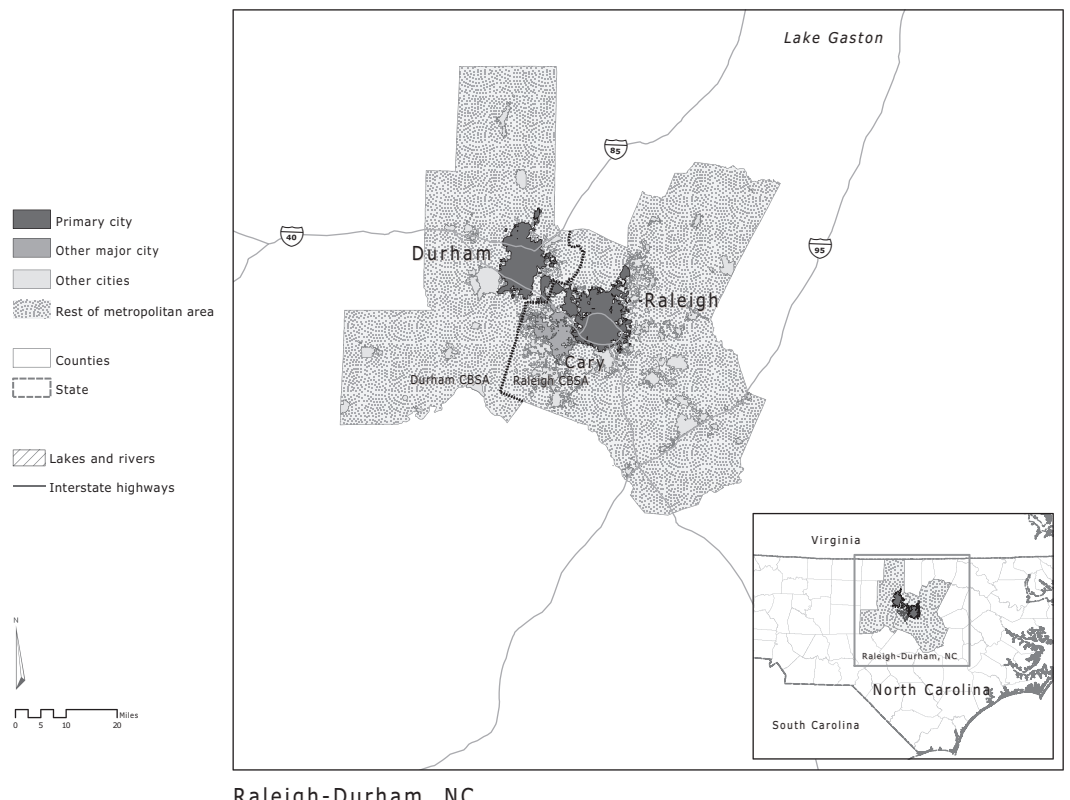

MAP 7.2. Raleigh-Durham Region.

I980 and 20I0. While the percentage living below poverty increased by nearly I 4 percent in the South and by nearly 30 percent nationwide, Raleigh-Durham's increased by only 5 percent. Similarly, while the South and the nation as a whole experienced a ro-percent increase in the income gap, Raleigh-Durham's has remained nearly the same over that period. Performance was worse in the 2000 s, with the region experiencing a nearly 50-percent increase in the proportion living below poverty and a I 5 -percent rise in the $80 / 20$ household income ratio during the decade. But the fact that the region had done so well in the I980s and I 990 means that over the thirty-year period, the region did substantially better than other regions in the South and the entire United States on both growth and equity metrics.

How has Raleigh-Durham been able to sustain its overall economic growth and do relatively better on some key equity measures? We think (along with many others) that the answer is partially rooted in the region's Triple Helix model of strategic information sharing and collaboration between government, business, and academia (Asheim, Cooke, and Martin 20I3; Marlowe and U. of Alabama 2009). A second important feature of Raleigh-Durham is the region's seeming commitment to racial equity, which is rooted in the region's efforts to overcome the 
legacy of slavery and to combat racial segregation in the I960s and I970s. While there are many other factors involved, we suggest that these two features have not only added norms of collaboration among diverse actors to the region's DNA but have also led to a strong, almost infectious sense of collective destiny in the region as a whole.

\section{Raleigh's Triple Helix Model of Collaboration}

One thing we found striking in our various treks across the country was that many regions had an origin story: the United Airlines executives who couldn't picture living in Oklahoma and thus sparked a renaissance; the Charlotte-based business leaders who realized that racial accommodation could be their New South selling point; the various garages in Silicon Valley that gave birth to business after business. In all these places (and others), the stories were well-worn and sometimes embellished (in one telling of the United Airlines story, the executives snuck into town with their wives, who then announced they couldn't live there, a twist which sounded great but could not be verified), but they are rarely told exactly the same way by every respondent. Not so in Raleigh-Durham, where our interviewees across multiple sectors recited the same narrative describing the founding of what they now call the Research Triangle and a spirit of collaboration they term the Triple Helix.

The story traces the origins of the modern region to the I950s, when forward-thinking leaders came together to address what they saw as the state's biggest economic problem: the brain drain. At the time, North Carolina had the second-lowest per capita income in the country, and most of the employment in the state involved low-wage jobs in farming, textiles, tobacco, and furniture (Link and Scott 2003; Learn NC n. d.). As a result, two-thirds of college graduates were reportedly leaving for higher-paying jobs elsewhere. This was an odd outcome, partly because the region had something that most did not: three toptier research universities-Duke University in Durham, North Carolina State University in Raleigh, and University of North Carolina in Chapel Hill-which were churning out some of the country's top thinkers in the quickly growing postwar high-tech industry.

To save the region's economy from continuing down the low-wage, low-skill labor market path-which provided no opportunities for the thousands of young people graduating from these universities every year-these leaders developed a plan to funnel the outpouring of talent 
into a regional high-tech industry (Rohe 20II). Conveniently for this plan, located between the three universities were thousands of acres of abandoned farmland. Where better, the leaders thought, to put a physical infrastructure for a cluster of innovators and research-oriented companies than in the middle of all three universities? This way, the companies could capture a highly skilled and educated workforce as they walked out the doors of local universities.

So, in the late I950s, business and university leaders with an economic interest in retaining talent brought local government officials, investors, and North Carolina Governor Luther Hodges on board to devote resources to the creation of Research Triangle Park (RTP). Its first tenant was the Research Triangle Institute, which started as a handful of scientists who received guidance and support from businesses, universities, and local government. Though the institute, now known as RTI International, was originally conceived of as the founding forprofit anchor tenant, it quickly converted to a nonprofit organization once leaders realized the park's potential to promote regional growth. RTI International has since grown to a staff of over 2,800 in more than 40 countries. And RTP has grown with it. Today, the 7,000-acre park houses 200 companies employing over 50,000 workers (Research Triangle Park 20I4).

Since the creation of RTP, the Triple Helix model-that is, collaboration among government, business, and academia-has become, as many interviewees told us, the "lifeblood" of the region. This model involves three dynamics. First, the role of universities in innovation is emphasized, as important entrepreneurial partners to government and industry. Second, increased collaboration between the three sectors leads to interaction and the co-development of knowledge and policy. And third, each entity takes on new roles in addition to their more traditional ones (Triple Helix Research Group 20I0). Indeed, the education arm of Raleigh-Durham's Triple Helix - which reaches beyond the top-tier research universities to include technical community collegeshas become central to the regional economic development strategy in that these educational institutions cater their programs and training to the changing needs of the region's high-tech industries. While the region once suffered from a brain drain, it now benefits from the coordination between businesses and educational institutions on job training and economic development policies that support innovation and offer financial incentives for companies and good jobs to locate in RTP (Research Triangle Region Partnership 2013). 
An early symbol of the Triple Helix model of collaboration was the establishment of the North Carolina Board of Sciences and Technology in I965. Now housed in the North Carolina Department of Commerce, the board was the nation's first advisory committee funded by a state legislature dedicated to growing and strengthening its science and engineering base through research grants to private and public institutions (Research Triangle Region Partnership 20I3). The collaboration has been institutionalized through nongovernmental organizations, too, like the Research Triangle Regional Partnership, a public-private partnership formed with the sole purpose of keeping business, government, and educational institutions in what they define as the thirteen-county region working together to develop pipelines of trained employees and innovation. Overall, it seems generally understood that each sector is a necessary element of capitalizing on the region's assets—research and innovation-and building a sustainable economy that can weather economic ups and downs. As one of our private-sector interviewees put it, this collaboration is necessary to continue "raising the tide for everyone."

\section{Race in the House}

While Raleigh-Durham's Triple Helix model is particularly institutionalized in regional practice, in some ways it is not so different from the university-business and public-private collaborations that have contributed to Silicon Valley's growth. What distinguishes Raleigh-Durham's regional ecosystem, however, is a strong grass-roots organizing and nonprofit sector that has proven effective in lifting up the voices of traditionally marginalized communities of color. Generally, equity advocates have built coalitions that have garnered enough political power to secure a place at decision-making tables. According to a local organizer, this long-standing movement has made North Carolina the symbol of "Southern progress" throughout history-from Reconstruction to the civil rights movement, the state has led the American South in passing progressive policies that benefit traditionally marginalized groups, particularly workers and African American communities.

A pivotal moment in the region's history that helped institutionalize a commitment to social and racial equity was Raleigh's struggleand relative success-in combating school segregation in the r960s and I970s. Like the rest of the country, and particularly amplified in the South, the region experienced residential segregation between Black communities, concentrated in Raleigh's urban core, and white 
communities, who were moving to suburban and rural areas in Wake County. The residential pattern shaped the demographic make-up of public schools and also influenced allocation of educational resources. In 1969, the US Supreme Court handed down its landmark decision in Swann v. Charlotte-Mecklenberg Board of Education mandating that public school districts use all means possible, including bussing, to desegregate schools; in I97I, nearly I2,000 students boarded busses in Raleigh (United States Commission on Civil Rights I972).

This happened in Charlotte as well-indeed, the suit was filed against the school district there-but what was significant in Raleigh was the concern of some of the region's key business and community leaders that the long-term effects of segregation (especially the gap in academic achievement) would have negative impacts on the regional economy. Certainly, predominantly Black schools in the urban core felt the impact from the disappearance of educational resources that accompanied white flight to affluent suburbs, but schools in rural Wake County suffered too. Business and political leaders were also worried about the economic impacts on downtown, including several school closures. While some conservative leaders saw the remaining schools, which were overcrowded and lacked adequate resources, as inefficient and wasteful of taxpayer money, most business, community, and political leaders united behind the idea that racial equity was not only the just thing to do but also the economically sound thing to do. And to achieve this, leaders knew that integration efforts (i.e. bussing) had to go beyond city boundaries.

In 1976, despite much opposition from anti-integration residents, the city and county merged school districts to create the Wake County Public School System (McNeal and Oxholm 2009). While the merger was unprecedented, what was even more striking was the fact that Wake County adopted a diversity policy, which required that all schools be racially balanced; a later iteration of the policy required socioeconomic balance as well (Grant 2009). While the Raleigh-Wake County merger initially faced opposition from neighborhood residents-indeed, the voters passed a referendum against the merger before it happened, but state law allowed the city and county school boards to do it anywayit is widely agreed that the region greatly benefitted in the long term. The Wake County Public School System has reduced the gap between Black and white and rich and poor students to a greater extent than any other school district in the country, and some argue that the region's school integration was key to enabling different communities to interact (Grant 2009). 


\section{A Collective Destiny?}

The long history of collaboration between educational institutions, government, and industry, as well as an institutionalized commitment to racial equity in the schools, seems to have fostered a strong sense of regionalism in the Raleigh-Durham region. As one interviewee described, while each place has its unique identity-Durham is the symbol of a strong Black middle class, while Chapel Hill is the tucked-away college town-collectively, there is a strong sense of place and pride at the regional level. For instance, at a biotech conference in 2013 we were told about, the Wake County Economic Development team did not go to simply represent Wake County; rather, they partnered with economic development representatives from the other eight counties in the region to recruit businesses and industries to the Research Triangle region as a whole. This kind of collaboration is typical, and while there is indeed competition among the jurisdictions, it is described as healthy rather than adversarial. Residents seem proud of the region's high quality of life, its relative affordability, and the numerous options for employment, housing, transportation, and neighborhood type.

In addition to the strong pride in place, there is a unique commitment to knowledge sharing. Many of our interviewees credit their "open source society," in which government agencies are transparent and make data easily accessible to everyone via online tools, as key to their success. In addition to local governments, particularly those of Raleigh, Durham, Cary, and Wake County, interviewees pointed to the Regional Transportation Alliance, founded by four of the region's largest chambers of commerce as the business voice for transportation initiatives, and the Research Triangle Regional Partnership as major sources of information on economic indicators. In terms of sources of information on social conditions, most of our interviewees involved in social justice work pointed to a single central source of data and research that grounds their movement: the North Carolina Justice Center, a progressive research and advocacy organization based in Raleigh but operating at the state level. In no other region we visited could interviewees so readily identify a central clearinghouse of information on social conditions that provides legitimacy to grass-roots organizing work.

But the tides of collaboration may be changing in Raleigh. For example, in 2009, local Tea Party candidates secured four of the nine seats on the Wake County School Board, with an agenda to dismantle the 
diversity policy-a symbol of the region's commitment to equity and the renowned model of reducing the achievement gap—and move back to the neighborhood-schools model. In $20 \mathrm{II}$, with a 5-4 vote, the school board ended bussing, or, as some describe it, initiated resegregation (Donnor and Dixson 2013). Not surprisingly, this action to dismantle a highly successful initiative caused a major community uproar, and the local NAACP chapter filed a civil rights complaint that prompted an investigation by the US Department of Education as well as re-evaluation of the school district's accreditation standing by the national accreditation agency AdvancED.

But the recent conflict around schools is a smaller indication of a seemingly larger shift that may be compromising the region's well-being and spirit of cross-sector collaboration. Since 2010 , conservative legislators in North Carolina have cut unemployment compensation for 170,000 people, increased taxes on low-income and middle-class residents (while cutting them for wealthy individuals and large corporations), rejected federal Medicaid funds for half a million residents, enacted anti-abortion legislation, severely slashed education funds, and adopted the nation's strictest voter-suppression law. In response, a diverse coalition of community, labor, and faith groups, anchored by the local NAACP chapter and its leader, Reverend Doctor William Barber II, have come together in Raleigh to hold weekly Moral Monday assemblies. Over the course of eighteen weeks in 2013, the Moral Monday movement swept to other regions across the state, attracting up to I0,000 protesters per assembly, and saw about $\mathrm{I}, 000$ people arrested in civil-disobedience actions (Dreier 2013).

The fight may be necessary, but it is dissonant with the diverse and dynamic epistemic community typified by the combination of a Triple Helix frame and some commitment to racial equity in education. Raleigh-Durham is rightly proud of its past as a model of multi-sector collaboration, but it will need to more effectively incorporate traditionally marginalized communities and fold equity actors into the tightly wound decision-making network that the Raleigh-Durham region has built over the last fifty years. It will also need to figure how to lead in a time in which polarization has become the political order of the day-and that will require business realizing that the immediate temptations of low taxes and less attention to inclusion hurt economic growth and quality of life in the long run. As we will see, that seems to be a lesson that has been well learned by regional leaders in our next case study, Seattle. 


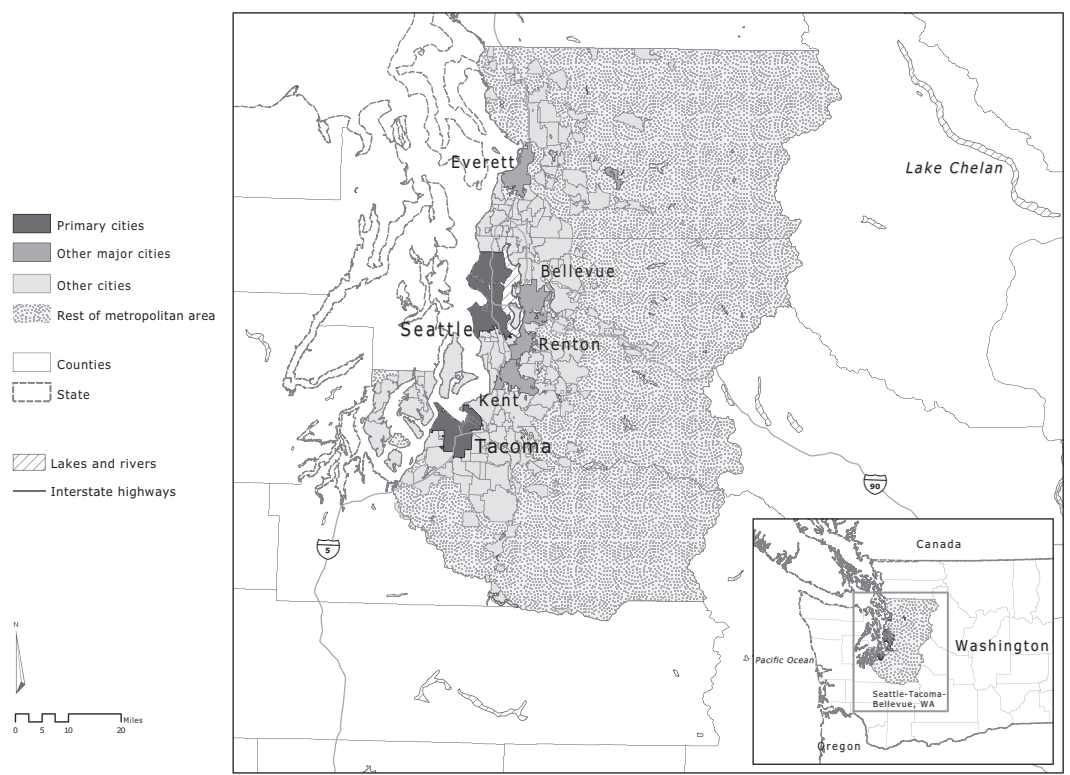

Seattle-Tacoma-Bellevue, WA

MAP $7 \cdot 3$. Seattle Region.

\section{SEATTLE}

We end our tour of America's high-tech regions in Seattle, the home of Microsoft, Amazon, and, as it turns out, an historical pattern of relatively inclusive growth. ${ }^{\circ 0}$ Between 1980 and 20 I0, Seattle's earnings per job increased at a higher rate (29 percent) than the West as a whole (20 percent), and its income equality was substantially better than the rest of the West (though still getting worse-the $80 / 20$ income ratio grew 5 percent between I 980 and 2010 , compared to an II-percent average for metro regions in the West). And this has happened even as Seattle has increased its global connections. Though it is only the fifteenth-largest metropolitan area in the country by population, Seattle has the sixth-highest export total, sending more than $\$ 47$ billion in goods and services abroad in $20 \mathrm{I} 2$ (Katz 20I4).

Innovative industries like aerospace and technology-the engines behind those exports-have helped create a strong regional economy producing a uniquely large number of high-quality jobs. In fact, one-fourth of the region's jobs are in STEM (science, technology, engineering, and mathematics) occupations; this is the fourth-largest share of any region in the country (Rothwell 20I3). While Seattle's largest increase in jobs 
between I990 and 20I0 was in lower-wage industries (like most places), wages in these industries increased by 37 percent (unlike most places). That Seattle has been able to maintain relatively good conditions at home while expanding its economic reach abroad sets the region apart.

How has Seattle been able to both grow faster and promote greater social equity? One obvious factor is simply the influence of a few major companies: Boeing, Microsoft, and Amazon. Boeing, the region's largest employer, has 85,000 employees in Washington, mostly in the Seattle

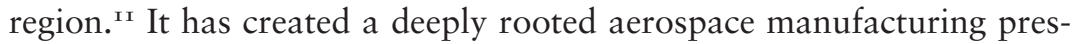
ence that continues to provide middle-class opportunities for people without higher education - the types of jobs that have declined in many other regions of the country. Microsoft, the region's second-largest private employer, has helped catalyze Seattle as a high-tech hub, providing over 40,000 jobs statewide. ${ }^{12}$ Similarly, Amazon has grown rapidly in the region since its founding in 1994 .

But other factors beyond the presence of these large firms have contributed to the positive trends in Seattle. The region has a strong early history of worker cooperatives and radical worker organizing by the Industrial Workers of the World (also known as the Wobblies) at the beginning of the twentieth century, which is said to have instilled a deep sense of collaboration for the common good in the Seattle region (Schwantes I994). More recently, a strong movement of multi-ethnic and multiracial organizing emerged during the civil rights era in the late I960s and early I970s. In this period, four key leaders from the Filipino, American Indian, Black, and Latino communities-later known as the Four Amigos-found common ground and united as a single political force, leading to important victories for each of their communities (Santos 2005). The region's cooperative roots, its tradition of bridge-building between unlikely allies, and its largely progressive political environment seem to have led to a mature method of mediating conflict and developing shared knowledge and action that permeates decision-making across the region today and has come to be known as the "Seattle process."

\section{The Seattle Process}

In the spring of 2014 , Americans had their eyes on Seattle. Not only had voters elected a socialist city council member, but this socialist was helping lead a winning fight to raise the city's minimum wage from $\$ 9.32$ to $\$$ I 5 an hour-the highest in the country. But this wasn't simply a case of mobilizing a majority of supporters to win a new policy. Rather, Seattle 
Mayor Ed Murray (who had run on a platform including a \$ I 5 -an-hour minimum wage) convened a twenty-four-person task force, the Income Inequality Advisory Committee, consisting of labor leaders, business leaders, elected officials, and community advocates, to collectively devise an agreement. Their charge was to formulate a policy that would have much broader support across the entire range of stakeholders (Weise 20I4). The negotiation process was contentious. Labor, community allies, and progressive city council members wanted the pay increase to happen fast, while business interests were either opposed or wanted to gradually phase in the increase and give greater leeway to small businesses, especially around tips and benefits. But by April 30-the last day before the mayor's deadline-the task force had put forth a proposal that was agreed to by 22 of the 24 members, in which small businesses will reach the S $5_{5}$ per hour minimum wage in seven years and large businesses will reach it in three. On June 2, 20I4, Seattle's City Council adopted it into law.

While this consensus-driven, multi-stakeholder, deliberative process may have appeared unique, in fact the Seattle region has a long history of convening diverse and often adversarial parties to build consensus on how to address local and regional problems. The process involves dialogue between all relevant stakeholders-most commonly businesses, unions, nonprofits, and community residents. Municipal staff frequently play the role of convener as well as translator of relevant data and analysis for both stakeholders and decision-makers. Only when all opinions are heard and consensus is reached do municipal staff and public officials make their decision. Those in Seattle even have a name for this phenomenon: the Seattle process.

Of course, regional leaders sometimes express frustration about the Seattle process, criticizing it for being painfully slow and for placing more value on talking than on doing. A 1983 Seattle Weekly article, for example, called it a process of "seeking consensus through exhaustion" (Moody 2004, 66). Others criticize the process as a way of actually avoiding making decisions. As one of our informants put it, Seattleites sometimes conflate talking with action. But such deliberative processes can have real impacts on people's perceptions, knowledge, and, ultimately, their actions. And because the Seattle process of consensus building is so deeply embedded, pushing individual agendas through proposals or policies without consensus is much less common, as was illustrated in the minimum-wage debate. Rather than construct a proposal in isolation, Mayor Murphy convened a task force, allowing opposing parties to get on the same page, so that by the time a vote 
came around, there was very little contestation; or, as one reporter put it, "without the anger and political bloodshed that's pitted employers against workers in other cities and has stalled efforts in Congress to increase the federal minimum wage" (Weise 2014).

Another example of the Seattle process at work-and perhaps one of the best illustrations of the frustratingly slow pace at which decisions can be made-is the reconstruction of the Alaska Way Viaduct, a doubledecked elevated section of State Route 99 that runs along the waterfront in downtown Seattle and carries I I0,000 vehicles daily. In I989, the Loma Prieta earthquake destroyed a similarly designed viaduct in Oakland, California, killing 42 people. After experts estimated a one-intwenty chance that Seattle's structure would experience similar destruction, government officials agreed to replace it. What followed, however, was a negotiation process between governments (ranging from city to state), businesses, unions, and communities that lasted for eight years.

During that time, the three main options raised were to dig a tunnel for the highway, to rebuild its elevated structure, or to simply eliminate it. Seattle's local political leaders, including then-mayor Greg Nickels and both local and state-level transportation officials, supported the tunnel, arguing that it would help downtown Seattle connect to the waterfront and promote tourism and economic development. But other state officials called it a waste of resources, likening the idea to the notorious Big Dig in Boston, and argued that building a new elevated highway was the most cost-effective way of ensuring that the needed traffic and goods-movement corridor was retained. The third proposal, removing the viaduct and replacing it with surface streets, transit, and local economic development, was supported by then King County Executive Ron Sims, smart-growth advocates, and a local coalition of community members and environmentalists. Unions, however, were strongly opposed to this option, as they were interested in the high-quality construction jobs that would come with either a tunnel or a replacement highway, while transportation officials and economic development experts felt that some kind of highway corridor was essential for ensuring the free flow of goods and people in the region.

Through negotiation and stakeholder advisory council meetings, a scaled-down hybrid tunnel option was developed. The option of a tunnel or rebuilding the elevated highway was put in front of the voters of Seattle in what was purely an advisory process; neither option gained a majority of support. Public officials decided to go ahead with the tunnel and began digging in 20I3. In what might be perfect symbolism 
of how process can stall product, the massive drill digging the tunnel (nicknamed Bertha) got stuck in place in December of that year. As of July 2015 , the drill was still undergoing repairs and tunnel digging had yet to resume (www.wsdot.wa.gov/Projects/Viaduct/Schedule). Clearly, the Seattle process does not resolve all conflicts, but the widespread consultation and debate among multiple stakeholders is striking.

The Seattle process is not just applied to region-wide policies or projects; it percolates down to smaller scales, too. In the mid-200os, CASA Latina-a nonprofit organization working to empower Latino immigrants, primarily day laborers, through educational and economic opportunities-was displaced from its trailer in the Belltown neighborhood of Seattle due to plans for reconstructing the Alaska Way Viaduct. The organization set out to find a site on which it could build a permanent worker center, and a potential site was identified: a vacant lot in southwest Seattle's Rainier Valley neighborhood, a working-class community that had suffered severe disinvestment over several decades. But some of the neighbors organized against CASA Latina, claiming that the center would bring more "riffraff" to the neighborhood rather than much-desired economic revitalization through commercial development (Jenniges 2004). On getting word that CASA Latina was considering building its worker center on the vacant lot in their neighborhood, and that the city had pledged $\$ 250,000$ toward the project, the local Rainier Chamber of Commerce wrote a letter to CASA Latina and the city requesting that they find a different site.

This of course caused conflict, fraught with emotion, between neighbors and workers-some of whom also lived in Rainier Valley. In response, the city intervened, threatening to withhold promised funds from CASA Latina until it quelled neighborhood opposition. The city provided a mediator, and the two parties, CASA Latina and the Rainier Valley neighbors opposing the worker center, undertook a six-month mediation process. By the end of the discussions, a majority of the original opponents had come around. While the site ended up being too expensive for CASA Latina to purchase, those who had originally opposed the center helped the organization find a new site nearby, and the city provided the funding it had promised.

\section{The Four Amigos}

Where did this rather unique and institutionalized process of consensusbuilding come from? Many interviewees point to the region's Scandinavian 
roots. At the turn of the century, about a third of Seattle's immigrant population was from Sweden, Norway, Denmark, or Finland (Eskenazi $200 \mathrm{I}$ ), and so, it is said, the Scandinavian norm of working in collaboration for the common good became part of the region's DNA. As hinted at earlier, other interviewees pointed to the legacy of the Wobblies-an organization founded at the turn of the twentieth century that aimed to abolish capitalism and promote a model of workplace democracy, in which workers would elect their managers-and to the presence of worker collaboratives, all of which left a legacy in which collective work was seen as leading to collective good (Saros 2009).

But a more recent period may have played an even larger role in shaping Seattle's now pervasive trend of working across difference. During the civil rights era in the I960s, Seattle's racial and ethnic minorities all seemed to have their particular struggles. The region's Native Americans were fighting for the land and water rights promised to them by the federal government; Blacks were fighting for racial equality in schools and universities; Latinos were uniting with farmworkers by protesting local grocery stores sourcing California grapes and lettuce; and Filipinos were fighting against invasive development that threatened displacement of residents and businesses from Seattle's International District—to name just a few.

During this time, movement builders from these various strugglesranging from the Black Panthers to the Blackfeet Indians of Montana to the Asian Coalition for Equity to the United Farm Workers-would hold meetings at St. Peter Claver Church, which allowed them to use the space cost-free (Santos 2005). As the church became a hub of civil rights activists across multiple movements, leaders from different constituencies realized that despite the specifics of their individual communities' plights, their struggle for social justice and equity was the same. ${ }^{13}$ Four leaders in particular formed a uniquely close bond, helping unite their communities across difference. These leaders became known as the Four Amigos and included Larry Gossett, a Black student activist; Roberto Maestas, a Latino leader involved in the farmworker movement; Bob Santos, a Filipino leader in the anti-displacement movement; and Bernie Whitebear, a Native American leader in the indigenous rights movement (Santos 2005).

With the understanding that they were much stronger together than they ever were apart, showing up to each other's fights became second nature. For instance, in 1970, the federal government decided to reduce the size of the Fort Lawton army post in northwest Seattle, freeing 
up land that had once belonged to American Indians. Severely lacking services, the American Indian community-led by Bernie Whitebearrequested that the city dedicate a portion of the land to an Indian Cultural Center as part of the original treaty the government had used to take the land in the first place. When discussions with the city failed, Bernie Whitebear led an organized group of community members called the American Indian Fort Lawton Occupation Forces in a three-month occupation of Fort Lawton, which eventually led to a negotiation with the city-mediated by the federal government- to grant the Indians a 99-year lease on twenty acres (what eventually became Discovery Park). The city also gave $\$ 600,000$ to the American Indian Women's Service League to help build a social services center (Whitebear I994). However, there was a secret ingredient in this victory: allies outside of the American Indian community. Before the occupation, Whitebear called on his friends-the rest of the Four Amigos-to rally their communities and participate in the occupation. So, alongside the American Indians were Black students and Filipino and Chicano leaders-and even some white progressives. ${ }^{14}$

This is but one of many examples of how the region's disenfranchised communities formed strong coalitions to achieve victories in the I970s. Each of the four grass-roots leaders went on to hold powerful positions in the Seattle region, mentoring other leaders along the way. Santos founded the Inter"Im community development corporation and is still a prominent leader in the International District and among Seattle's Asian American community. Whitebear founded the Seattle Indian Health Board and the United Indians of All Tribes Foundation. Maestas formed El Centro de la Raza. Gossett founded the Central Area Motivation Program and then went on to elected office as part of the King County Council. The work of the Four Amigos in the late I96os and throughout the I970s left a legacy not only of working across difference but also of paying attention to racial equity and social justice in the Seattle region.

\section{The New Demographics and the Future of Collaboration}

Since I980, Seattle's population has grown by 64 percent-and, as in most American regions, much of this growth came from populations of color. In I980, almost 90 percent of Seattleites were white; in 2010, less than 70 percent were. During this time, all racial minority groups, except American Indians, increased their proportion in the region. 
In particular, Latinos grew from 2 percent of the population in 1980 to 9 percent in 2010; Asian Pacific Islanders, from 4 percent in I980 to I 2 percent in 20I0; and Blacks from 4 to 5 percent of the regional population over that thirty-year period. These trends partially reflect the increasing share of immigrants making up the Seattle region. In I980, immigrants made up 7 percent of the population; by 20I0, this had more than doubled, to I 6 percent. By 2040, whites will only make up 45 percent of the population-less than the projected share nationwidewith Latinos and Asian and Pacific Islanders each at about one-fifth (2I percent and I 8 percent, respectively).

While these are dynamics facing much of the country, Seattle may be better poised than other regions to work its way gracefully through racial change. The legacy of multi-ethnic and multi-racial organizing has influenced the region's institutionalization of the principles of equity and social justice in its government agencies. Spearheading this work is King County. In 20I0, Ron Sims, then county executive, founded the Social Justice and Equity Team. (In I985 Sims was the first African American elected to the King County Council, and in 1997 he was the first African American elected county executive.) The initiative was primarily in response to racial disparities in the region, including education gaps between whites and Blacks as well as the disproportionate number of boys and men of color being incarcerated. But it has led to transformational efforts in many arenas.

For example, all public health department staff must participate in a two-day training on institutionalized racism. Second, the principles of "fairness and justice" are among the top priorities in the county's 2010 strategic plan. Third, the team successfully pushed an Equity and Social Justice Ordinance requiring all county departments (not just the executive branch) to consider the social justice and equity impacts of all decisions, particularly on people of color, low-income communities, and people with limited English proficiency-and if the impacts are negative, to do something about it. As part of the ordinance, the Social Justice and Equity Team developed an Equity Impact Review Tool, which is both a process and a tool "to identify, evaluate, and communicate the potential impact-both positive and negative—of a policy or program on equity" (Albetta and Valenzuela 2010).

The city of Seattle has a similar Race and Social Justice Initiative, focusing explicitly on institutionalized racism. So far, the initiative has, in good Seattle-process form, pulled together a community roundtable to strategize about ending racial inequalities; helped double the 
government contracts with women- and minority-owned businesses; grown community engagement in historically under-represented neighborhoods; required all city departments to provide translation and interpretation services; provided over \$I million through a Neighborhood Matching Fund; and, following the lead of the county, put 7,000 employees through institutionalized racism training and developed a Racial Equity Toolkit to ensure the consideration of equity in decisionmaking processes (City of Seattle 20I4a). While Seattleites might take it for granted, this type of institutionalized attention toward equity at multiple levels of government is unprecedented.

This sense of inclusion extends to regional planning efforts, too. While most of the growth in the I980s and I990s was in the suburbs, in the 2000s, growth in the urban cores and in the suburbs was about equal: I 2 percent and I 4 percent, respectively. Now, low-income communities of color in more urban areas of the Seattle region face the threat of gentrification. Partly in response, local and regional government agencies, including the Puget Sound Regional Council, have collaborated to develop a Growing Transit Communities initiative, in concert with the region's voter-approved $\$ 25$ billion transit build-out, in an effort to locate housing, jobs, and services close to transit, with a focus on ensuring affordability. ${ }^{15}$ For instance, the city of Seattle is granting transit-oriented development acquisition loans that help developers purchase vacant land near light rail stations to build mixed-use projects that include affordable housing and commercial space for small businesses and community facilities (City of Seattle 20I4b). Indeed, the city of Seattle has required the development of affordable housing for decades. Starting in I98I, Seattleites voted to tax themselves to fund affordable housing for low-income workers, seniors, and homeless people; through this levy, the city has funded over 10,000 affordable units (City of Seattle 20I4c).

Despite this fascinating history of incorporating equity into governance and planning, we also heard concerns that regional discussions can be too shallow-able to bring stakeholders together to find common interests, but less effective in dealing with bigger substantive differences in interests or perspectives. As the region becomes less white and more racially diverse- and as that population shifts southward through the region, particularly because of high housing costs in the central city-the Seattle process will need to adapt, and broaden the leadership at the table. In addition to concerns about housing costs, transportation options, and employment opportunities, a major concern of regional 
leaders moving forward is the level of preparedness-or lack thereofamong Seattle-born youth to participate in the region's booming STEM sectors. ${ }^{16}$ All that said, Seattle offers a remarkable example of a region at the leading edge of America's knowledge economy that has also built a set of knowledge communities where listening to others is valued, collaboration is second nature, and equity is at the very least an actively voiced concern.

\section{WHAT YOU DO KNOW CAN HELP YOU}

Silicon Valley, Raleigh-Durham, and Seattle are all iconic high-tech regions-places that have been relatively successful in the development of the cutting-edge technology industries that are at the core of the "new economy." Each of the three regions has also become well known for its own particular brand of collaboration. Silicon Valley's "regional advantage" has been linked to its open labor markets and collaborative culture (Saxenian 1994). Raleigh's Triple Helix of public-private-university collaboration has been celebrated for promoting innovation and growth (Research Triangle Regional Partnership 2015; Triple Helix Research Group 20I0). And Seattle even has a "Seattle process" designed to ensure substantial communication among multiple stakeholders.

On the one hand, all that makes sense. As multiple authors have argued since at least the I990s, in an economy driven by technological change, information sharing, knowledge development, and cross-sector collaboration are critical factors in economic success (Brandenburger and Nalebuff 20II; Kanter 1994; Logan and Stokes 2003; Lowitt 20I3). But in two of our knowledge regions, equity has also been a fairly important concern. Leaders in Raleigh-Durham suggest that the region's school bussing plan was central to its success, and in Seattle, prominent race and social justice initiatives have been institutionalized in city, county, and regional planning processes. In Silicon Valley, in contrast, most people talked about a highly divided region, with significant limitations to the extent to which concerns about social equity find their way into regional decision-making processes.

Of course, the nature of regional communication and collaboration is not the only factor shaping growth and equity in each region; as usual, structural elements play a key role. The continued presence of Boeing and related manufacturing industries in Seattle, and the presence of the state capital and related high concentrations of public-sector employment in Raleigh-Durham, for example, have been important in 
ensuring relatively stable middle-income jobs in both regions; by contrast, Silicon Valley has seen its manufacturing slip away and an hourglass employment and earnings structure emerge in its place. Yet the existence of what seem to be particularly diverse and dynamic epistemic communities in Raleigh-Durham and Seattle-and the ways in which entrepreneurs in those regions seem more regionally rooted than in Silicon Valley-are, we think, factors that do help shape an environment in which growth is encouraged and equity is more achievable.

These cases also suggest that being at the cutting edge of technological change does not necessarily have to produce economic inequality or social disconnections. In both Raleigh and Seattle, public policy (education in one case; housing, transit, and minimum wage in the other) has been used to temper the economic disparities that high-tech development can produce, and communicative strategies have helped hold interests together. As such, these cases illustrate the possibilities for an America buffeted by technological change, global competition, and rising divides by skill and income. In the chapters that follow, we stand back from the details of these and the other cases to examine in more depth how such communities of concern develop, how such processes of collaboration can impact growth and equity outcomes, and what all this means for economic theory, policy practice, and national politics in the twenty-first century. 